\title{
Theme III: Social Reproduction
}

Under the theme of social reproduction a number of specific topics were discussed-relations within the family, the nature of the link between class and kin relations, population control policies-as well as more general topics such as the role of legislation in bettering women's position, that of religion in maintaining male dominance, and the social determinants of fertility. The topic was divided into two sections: in the first the plenary and other workshop papers centred around questions of the family, ideology (including religion) the role of the state (in particular in legislation).

The plenary paper ${ }^{1}$ starts from the premise that the capitalist mode of production is unable to reproduce its own conditions of existence within the capital:labour relationship. The authors then go on to make several points. They argue for a distinction between capitalist and non-capitalist relations of production so as to clarify the differences in the relations of different sectors of the population to capital accumulation and the different forms of contradiction arising from these relationships.

The specific requirements of capital for labour entail that labour be reproduced outside capitalist relations of production, and this process of reproduction is mediated by other structures, e.g. the family, the State, the so-called peasant economy, rather than entering into a relationship with capital at the point of production. The conditions under which the reproduction of the labour force take place vary enormously, both according to the particular phase of capital accumulation and according to the struggles of the actual and potential labour force over the conditions of reproduction. Part of this struggle centres around the wage. The ways that wages are distributed to non-waged members of the labour force and differences in the uses made of male and female wages have yet to be properly analysed so as to understand the relation of the wage to overall reproduction of labour. These shortcomings are

1. Women and Social Reproduction by Olivia Harris and Maila Stivens. highlighted in the debate on domestic labour. In the literature on this debate the household was always treated as if it were a unit whose subsistence was derived from the male breadwinner's wage.

The existence of a relative surplus population, both the result and an intrinsic feature of the continuing accumulation of capital, together with the particular features of the labour performed by women in the daily and generational reproduction of a 'free' labour force, are crucial in structuring the position of women in all parts of the world where the needs of capital accumulation dominate the economy.

The ways that kin relations under capitalism structure, in both their ideological and economic aspects, processes integral to social reproduction were outlined. Kin relations among the urban middle and working class tend to become femalecentred: this, Stivens suggests, is integral to kin relations under capitalism, and arises out of women's primary location within the reproductive processes (both of labour power and of relations of production) embedded within kin relations.

The importance of the State was underlined as an agent in the reproduction of the labour force, and as an arena for activity concerned to transform the overall conditions of reproduction, including domestic labour. Though legislation can be beneficial to women, it is also ambivalent, and should be seen as a necessary but not sufficient condition for the improvement of women's position. In the discussion that followed, it was pointed out that the relationship between legislated rights and discrimination against women was ambiguous. Women need protection against certain forms of exploitation, but this can lead to their exclusion from whole areas of activity. For example, specifying the conditions under which women may work, or legislating for equal pay may have the effect of their ceasing to be employed at all. Many of these points were taken up again in the workshop on Politics and Legislation. 
Discussion also focused on the usefulness of the concept of the reserve army of labour in analysing women's position: if there are high rates of male unemployment, should women even be considered as part of a reserve army? Again women's domestic duties mean that their entry into the labour force lacks the flexibility of a 'perfect' reserve army. It was felt that the concept must be used with caution since it is questionable whether, even in periods of full employment, all women will be drawn into the labour force.

The ways in which the State creates and reinforces women's subordmate position within the household was also discussed, notably in terms of lack of provision of child-care facilities, adequate care for the elderly and so on, but also in terms of domestic labour as a substitute for welfare legislation. As evidence of this view, one participant quoted the President of Mexico: "We do not need a system of social security as long as we have the Mexican wife". A similar statement by Chairman Maothat China is too poor to release women from their duties of caring for the very young and the elderly -shows that this view is not held only by proponents of capitalist forms of development.

While only one workshop was devoted explicity to marriage and family, it was a constant theme of many papers presented at other workshops, and of discussion in general. Stivens in her plenary presentation suggested that the concept of 'family' is highly ambivalent, and analytically confused; it refers both to a set of particular kim relations and to an economic unit. While the family as an institution derives its strength and particular characteristics from the combimation of these aspects, it is important to separate household organisation from kin relations. After lengthy discussion it was agreed that more sophisticated analyses of the family, its internal power relations and its relation to the wider economy are needed.

Deere's paper ${ }^{2}$ directly addressed the problem of the relationship between changing relations of production and economic structures at the widest level, and different family forms. Families are structured in a number of complex ways and while it is essential to understand the links between household composition, the social formation and the world economy, these links are indirect and interactive. In some circumstances the form of the residential unit is directly structured by a particular type of economic enterprise (for example early 20th century haciendas of northern Peru), in others it is an effect of wider economic forces, but

2 The Differentiation of the Peasantry and Family Structure: $A$ Peruvian case study by Carmen Diana Deere. structured in a mediated way (for example nonhacienda households where a major source of income comes from migrant labour).

White ${ }^{3}$ argues that the ways in which relations of exploitation, that is, class relations, are connected with kim relations and family structures, have been insufficiently analysed. While the Marxist tradition acknowledges the existence of relations of exploitation withm the family, in Vietnamese land reform legislation a model of the family as a harmonious unit was employed. Nonetheless many smallholding peasants were classified as belonging to the landlord class on the basis of specially acute forms of exploitation of female and child labour.

The frequent invisibility of women's economic contributions was pointed to by Schmukler.* In her study of the economic organisation of small grocery stores in Buenos Aires, she found that the wife's labour was essential in order to keep these enterprises viable in a context of tight profit margins. A strong correlation between the lifecycle of the grocery enterprise and that of the family was noted. She poimts to the importance of understanding the role of women in the reproduction of labour which is not directly dependent upon capital-in other words, how the unity labour power:means of production is ensured in the future through the reproduction of the family labour force. Schmukler also stressed the need for analysis of the sexual division of labour within the family and its consequences for the type of work allocated to women, and for comparison of the work allocated to different family members in different social classes.

Two papers in other workshops $\left(\mathrm{Safa}^{5}\right.$ and Martinez-Alier ${ }^{6}$ ) also paid particular attention to

\footnotetext{
3 Family and Class in the Theory and Practice of Marxism

4 Wife and Family in the Traditional Urban Petit Bourgeoisie

5 Women, Production and Reproduction in Industrial Capitalism by Helen Safa.

6 The Subordination of Women and Productive Labour by Verena Martinez-Alier.
} 
variation in family forms and the relationship of this to wider economic structures. The former showed how differences in family structure of female workers in the garment industry as between Saõ Paulo, Brazil and New Jersey, USA, can be related closely to different employment opportunities. Martinez-Alier used her research on family structure in the upper classes in nineteenth-century Cuba and in Brazilian coffee plantations this century to argue that while family structure changes radically according to specific historical circumstances, it is in the institution of marriage itself that women's subordination must be located. She suggests that an over-emphasis on the economic aspects of women's subordination, and on the economic functions of the family, obscures a fundamental aspect of women's subordination: that women must be controlled by men so as to allocate the next generation to specific social positions within a power structure.

Two further papers (von Werlhof ${ }^{7}$ and BennholdtThomsen $^{8}$ ) argued that the analytical separation of family and economy is mistaken. Family relations, and the different activities normally performed within households, should be treated directly as part of capitalist relations of production. Bennholdt-Thomsen argued that an adequate understanding of the reproduction of human labour can only be reached by integrating the reproduction of subsistence into political economy. Von Werlhof questioned the systematic separation of sexuality and economy and suggested that any overall analysis of capitalism must include an account of the ways in which sexuality, as one aspect of social relations, is exploited by capital.

Many participants were concerned to deconstruct the notion of family into the different types of relationships contained within this single concept, so as to understand the ways households are structured, how these structures are to be analysed within the context of the wider economy and how they are related to different forms of subordination. There was disagreement on how precisely to conceptualise such issues, and the degree to which they should be separated analytically, but general consensus that mechanistic oppositions, such as that between family and class, or between domestic and social labour, should be avoided. The need to look at the role of the men/the family of differing social classes was emphasised: too great a concern with the proletarian family and the reproduction of free labour may divert attention

7 Sexuality and Economy by Claudia von Werlhof.

8 Subsistence Reproduction and Extended Reproduction by Veronika Bennholdt-Thomsen. from the importance of investigating relations based on control of inheritance and the reproduction of private property (particularly smallscale family enterprises).

The implications of development programmes which treat the family as the basic indivisible unit of society were discussed. Such a view obscures hierarchical relations both of gender and of age, and inhibits understanding of the nature of conflict of interests between members; it also cannot explain why in all societies known to date, these conflicts have been resolved in favour of men.

In the workshop on Politics and Legislation discussion centred around the nature and effects of positive legislation for women. It was felt that such legislation tends to be the outcome of particular political conjunctures, and that these therefore need to be analysed in greater detail, before any clear understanding of the role of legislation in furthering women's struggles can be reached.

Some general points concerning women's position in Arab countries and the ways that this is being transformed by the impact of capitalist expansion were made by. Baffoun. ${ }^{9}$ Liberalising tendencies in many Arab states have to be understood in terms of the dynamic of capital accumulation and its changing requirements for the structure of the labour force. As an example of these processes she gave a detailed account of the liberalisation of women's position in Tunisia through legislation and the provision of family planning services. Baffoun also discussed the problem of a backlash response to progressive and liberating measures arguing that this derives from the political weakness of newly independent states and their inability to satisfy the social and economic needs of the mass of the people. The frustration of the poor (especially in view of the known corruption of the rich) then can become channelled into Messianic or traditional religious movements which, like other conservative movements, repudiate those measures and in particular those which challenge male authority.

Moura $^{10}$ gave an account of the family planning movement, and of her own experiences in trying to make family planning available in pre-1974 Portugal. In marked contrast to the case of Tunisia, strongly pro-natalist policies were supported by both Church and State, and by a pre-

\footnotetext{
9 The Venture of Arab Women by Alya Baffoun.

10 Successes and Difficulties in Family Planning by Eugenia Moura.
} 
vailing machista ideology. In spite of the strength of the opposition, legislation to legalise family planning has been introduced. The overall antagonism of the medical profession to providing abortion (still illegal) and contraception is still a major problem; but the family planning movement has made a consistent effort to make such facilities available without putting positive pressures on women to limit family size. The discussion centred on the extent to which pro- or anti-natalist tendencies in legislation had to be understood in terms of ideological rather than strictly material factors (e.g. labour needs, standard of living). In general the role of religion in this and in other things was singled out for special attention in the formulation of legislation attacking women.

The achievements and limitations of the Jamaica Women's Bureau, set up in 1975, were analysed by Phillips. ${ }^{11}$ Since approximately one third of all households in Jamaica are female-headed, and women comprise 40 per cent of the country's workforce, the problems faced in improving women's overall position are very different from those of many developing countries. For example, female unemployment is far higher than male and government's employment strategy is biased in favour of women. However, in the present circumstances of financial stringency and high inflation, positive measures in favour of women are seen as luxuries and have been severely cut back, with the exception of family planning services.

Phillips made two points: first, she raised the problem of the interrelationship of positive legislation for women and the political and economic climate which produces it. Even where the particular concerns deriving from women's primary responsibility for rearing children are recognised, all too often women are the first to suffer from economic recession. Furthermore cutbacks in social services and legislation improving the position of women are often a condition of international monetary loans.

Secondly she noted that the apparent independence of women from men can be misleading: while women may not be directly subordinate to a particular member of their male kin, they are nonetheless subject to an overall culture of male dominance.

In the discussion of these three papers the contradictory nature of much of the legislation specifically directed at women was underlined.

11. Government Policy Towards Women by Elizabeth Phillips.
Even positive legislation is ambivalent: it is selectively applied, and there are rarely sufficient guarantees to make it fully effective in the long term. The role here of a women's organisation was signalled. The usefulness of womens bureaux and similar institutions was discussed in terms of where they should be located within the government structure itself. There was general agreement that they must be in a structural position which allowed them to affect the policies of different ministries. Their relegation to the sphere of health and social services merely underlined a social welfarist attitude towards women.

Specific discussion on ideology and its materiality was provoked by Islam's paper, ${ }^{12}$ which vividly described the severe social handicaps placed on women and the way their inferior position is reinforced ideologically through representations of women in the socialisation process and in popular culture. She related the forms of submission and dependence expected of women to cultural tradition, and emphasised the strength of such tradition by showing how such forms are recreated in quite different economic circumstances.

Katoppo ${ }^{13}$ was concerned to evaluate the significance of linguistic change in the forms of addressing men and women, and to relate this to the imposition of non-indigenous gender stereotypes by colonialism. The adoption in Indonesia of words derived from Sanskrit, Arabic and Dutch went with an adoption of bourgeois values in which women were seen as dependent on men, whereas in Malay language and culture great respect is accorded to both women and men.

It was generally felt that the conference had not devoted enough time to ideology and that this replicated the wider situation in which progressive social movements and people concerned to better the conditions of women's lives paid insufficient attention to the power of ideology. Its frequent appropriation, especially through religious discourse, by those inimical to such changes was stressed. It was argued that male domination over women is so legitimised in ideology that women are often prevented from even being fully conscious of the forms of their own subordination.

In this same context participants noted with concern the failure of the Left, and of progressive political movements in general, to perceive that

\footnotetext{
12 Effects of Tradition and Superstition on Women's Status:

13 Language as an Indicator of Subordination by Henrietta Katoppo.
} 
women have specific interests, separate from those of men. The result of this failure has been an abandonment to their opponents of the ideological and economic issues concerning the family. The Right has been permitted to present the family as the source of social stability, the bastion of opposition to all threats to the established order and to play upon the failure of the Left to address the immediate problems of domestic life. In addition, otherwise progressive movements have frequently reproduced some of the worst features of male/ female stereotyping in the society at large (for example, the ideology of machismo) and have therefore offered women no alternative to the dominant ideology. The result of this has inevitably been an alienation of many women from the aims and actions of progressive movements which fail to address their most pressing problems.

A special session was organised to discuss religion and its effects on women's position. There was general agreement that organised religion, even those such as Hinduism which are not based on the worship of powerful male gods, is patriarchal in character. Further traditional religious beliefs are a powerful tool in the hands of those who are antagonistic to the improvement of women's position. In many cases attempts to produce progressive legislation are opposed on the grounds that any change in traditional family structures (and male authority within the family) is at the root of social problems. Women are thus pressurized to conform, both by psychological and by directly repressive means. As a corollary many participants commented on the highly complex inter-relation between religion and political movements, even where such movements are in theory anti-religious, or even Marxist.

It was felt that analyses of development and development strategies themselves took too little account of these cultural and ideological constraints. Nor did agencies and others promoting development make other than half-hearted attempts to confront outright opposition or passive resistance to measures designed to improve women's bargaining power in clearly patriarchal and oppressive regimes. All too often such behaviour is justified on grounds of non-interference in others' affairs-a justification which is never valid in cases where economic processes are concerned: for example an IMF loan.

The second part of the theme-social reproduction -was devoted to a discussion of the social determinants of fertility and included both papers criticising the literature and giving case material and a more wide ranging analysis of population control policies which seek to limit fertility in the Third World.

In the plenary Young ${ }^{14}$ attempted to bring together both these issues. The paper made crucial conceptual distinctions in order to clarify feminists' stance towards population control programmes. Birth control, women's and men's control of their own fertility, implying for women also control of their own sexuality, must be differentiated from population control or the control of other people's fertility by governments and international agencies. Unrestricted access to birth control techniques must be recognised as the right of every woman and a crucial determinant of her ability to define the course of her own life. Despite the importance of these distinctions, the two are frequently conflated because historically the two movements have often overlapped. Male socialists have been led to oppose birth control as a population control measure based on Malthusian principles, while today international agencies may appear to adopt feminist birth control demands but only in order to further population control campaigns.

Intervention in reproduction, Young argues, has always existed, and to illustrate this she examines variations in the age of marriage, rates of nuptuality and completed family size. Moreover, the practices of infanticide, abortion and birth control in pre-industrial societies, and during the transition from feudalism to capitalism in Europe, when socially enjoined, are thought to be related to socio-economic processes or to changes in demand for labour, but this relation remains unspecified. Within capitalism it is suggested that population levels may vary independently of any postulated 'need' of capital, since labour power is produced and reproduced outside the capital:labour relation. Nonetheless studies of the proto-industrial family in rural Europe show a clear relation between dependence on wage labour, low return to labour, use of child labour, decreasing age of marriage, and high fertility.

The crucial problem for feminists is to understand how fertility limitation practices, both biological and social, influence gender relations. The critical determinant here is argued to be the age of marriage for women, itself an important factor in varying fertility rates.

\footnotetext{
14 Socialism and Feminism, Population Control and Birth Control (Part 1) The Social Determinants of Fertility (Part 2) by Kate Young.
} 
Four other papers were presented, two of which dealt with the economic factors which may help to determine family size, and two discussing population control programmes and their effect on women's position.

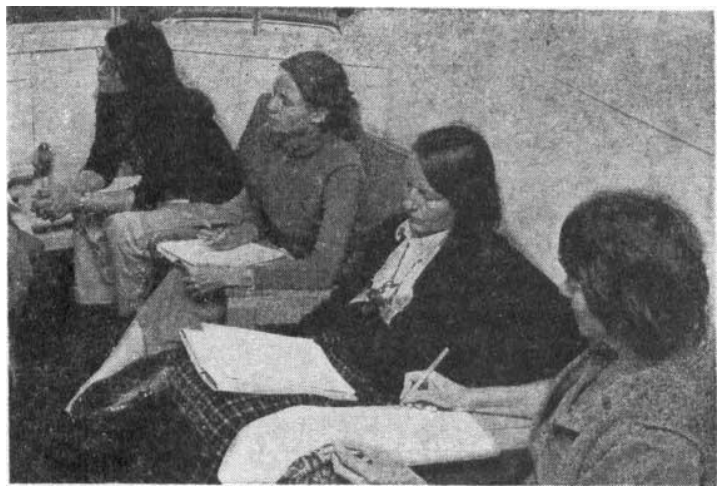

In the first Monsted ${ }^{15}$ compared desired family size under different conditions of land use, population density, household division of labour, and child labour. She highlighted the limitations of a cost benefit, rational-choice model for predicting desired family size, and argued that so-called economic benefits in rural areas are insufficiently specified, since much child labour is used in household domestic work. The concept of 'desired family size' was also found to be inadequate, varying more with the age of the mother than with socio-economic variables. Except under extreme economic pressure, land-holding families appear not to hold any exact idea of the family size desired, while landless wage-earning families did want large families.

Monsted concludes that, although women are the appropriate informants regarding child labour and family income in rural Kenya, and they tend to favour smaller families more than men, in fact men have considerable power over the determination of family size. Monsted substantiates Young's point that it is difficult to relate individual family choices to actual changes in population size; the framework within which such choices are made includes not only socio-economic processes but gender relations, and may be determined by events beyond the understanding or ability to predict of the decision-making couple.

Safa ${ }^{16}$ addresses the problem of relating women's fertility and family ssize to the changing require-

15 Conditions for changing Family Size in Selected Areas in Rural Kenya by Mette Monsted.

16 Women, Production and Reproduction in Industrial Capitalism by Helen Safa. ments of capital, and suggests working class survival strategies as the intervening variable between capital's requirements (expressed in employment opportunities) and family size. In a comparison of age/marital status/family size of women garmentfactory workers in Saõ Paulo (Brazil) and New Jersey (USA), she shows how the need for the working class to subsidise the upgrading of skills led to a high rate of labour participation among married women in the US when their children's potential wages are lost in the long period of schooling. In Saõ Paulo, however, steadily declining real wages and increasing levels of infant mortality mean that families must be large enough to ensure that several wages contribute to household expenditure.

Some doubt was voiced by participants on the validity of making a comparison between conditions of capital accumulation in the first half of the 19th century in the USA, and in Brazil today. The importance of ideology in structuring certain views of gender identity (machismo of men and marianismo of women) was stressed. Deere also reported that in North Peru size of family is related to access to land (households of the middle and rich peasantry average 6.4 as against landless and small-holder households of 5.6) as is household composition-53 per cent of the richer landowning households being extended while 67 per cent of poor households were nuclear.

The papers on population control programmes dealt with the intervention of metropolitan governments and international agencies in the social relations of reproduction in the Third World. While the main focus of such programmes is biological intervention to reduce women's fertility, it was suggested that they are increasingly attempting to intervene in the social relations of reproduction.

Minkin's paper ${ }^{17}$ explored the political ramifications of US family planning policy in Bangladesh, as well as the specific effects of the mass inundation programme supported by US AID. US pharmacological industry benefits both from the opening of new markets as a result of US government sponsored family planning programmes, and from their ability to offload drugs there which have been banned in the West. In addition, indiscriminate pill dissemination has unresearched but potentially serious effects on the health of women and their children, and may also increase the risk

17 US Family Planning Policy and the Implications for Bangladesh by Stephen F. Minkin. 
of pregnancy. Lastly, he suggested that pills banned in the West are still being supplied to the Bangladesh family planning programme, which does not receive information routinely supplied by drug companies to doctors in the United States on the dangers associated with various types of pill.

In the discussion other participants further elaborated on drug dumping in the Third World. One noted that future legislation making the receiving government responsible for deciding whether a drug is suitable for its population was likely to diminish US Government responsibility in the matter. It was felt that this issue was one around which women could organise both nationally and internationally.

Young's presentation ${ }^{18}$ underlined the fact that in the conceptualisation and design of population control programmes, as in aid programmes aimed at women, women's future role in society is already determined for them. The aim of such programmes is usually to make women more productive agricultural producers, more effective providers of health care and efficient controllers of their reproductive potential. To ensure this women are to be given education and encouraged to take up economic activities, which in turn may help the age of marriage to rise (an important determinant in fertility rates).

The discussion of these papers was quite wideranging. The increasing number of Caesarian births was commented on and it was suggested that this may be related to the widespread use of induction techniques to bring on birth. This practice in turn may be related to the personal interest of doctors in scheduling deliveries at their convenience, or even to the profit motive.

The point was frequently made that health and politics are not unconnected: the drug industry consistently reports one of the highest rates of profit in the manufacturing sector. The control that multinationals exercise over the research and development as well as production and distribution

18 Population Control Programmes by Kate Young. of birth control technology was noted. Whether we are talking about Nestlé and bottle-fed babies, or the massive and indiscriminate dissemination of the pill, we are evidencing the growth of corporate profits. The fertility management industry's concentration on development of expensive and potentially harmful chemical means of fertility control (i.e. hormones, drugs, etc.) rather than inexpensive mechanical and barrier methods was deplored.

At the theoretical level the contradiction between the size of the population and capital's need for a reserve army was discussed. There was disagreement on whether one could suggest, as did the plenary, that labour is reproduced outside labour: capital relations and thus, that there is no necessary correspondence between population growth rates and capital's requirements. It was argued that the only way to resolve this is to analyse how this contradiction is mediated with changing material conditions of production.

In the discussion of the possibly hidden element of population control in many women's programmes two basic points were made. While we share a basic concern over the question of the effects of certain methods of birth control on women's health, and the use of population control programmes in subjugating women, we cannot forget that women's control over their own fertility must be considered a basic, inalienable right. The struggle with machismo is a real one: while children provide men with status, it is the woman who is left to take care of them whether the man provides support or not.

Secondly, the cooption of feminist issues by the international agencies cannot be met by feminists with simple rejection: rather it was argued that feminists should support programmes which give women increasing access to education and employment, at the same time critically examining the content of such education and the conditions under which women are required to work. The development of women's capacity to analyse their own situation and to experience alternatives to dependence must be the aim of all women's programmes and it was felt there was a good possibility for organisation around this issue. 